\title{
MICROBIOLOGICAL HAZARDS ASSESSMENT COMPARISON AMONG THREE DIFFERENT DEHYDRATION METHODS OF CHAMOMILE AND CALENDULA
}

\author{
EL-SAYED, O. A.M. ${ }^{1}$, Y. I. SALLAM ${ }^{2}$, A. M. EHAB ${ }^{2}$ and AMAL H. MAHMOUD ${ }^{1}$
}

1. Food Technology Research Institute, Agriculture Research Center, Giza, Egypt

2. Food Science and Technology, Faculty of Agriculture, Cairo University, Giza, Egypt

(Manuscript received 15 May 2012)

\begin{abstract}
The assessment of microbiological hazards is established to evaluate the effect of HACCP pre-requisite programs implementation and the methods of dehydration on microbiological hazards in some medicinal and aromatic plants. Gap analysis had been established on three models of dehydration to assess the probability of HACCP pre-requisite programs implementation. One of these models was natural dehydration which was not hygienically illustrated and we couldn't apply to implement HACCP pre-requisite programs especially cleaning and disinfectant program. Others were solar and oven dehydration models which were good illustrated to apply HACCP pre-requisite program. The study compared the microbiological hazard among these models of dehydration of two deferent medicinal and aromatic plants which were Calendula (Calendula officinalis) and Chamomile (Matricariachamomilla). Swaps were taken from workers hands and products contact surfaces of each dehydration models. samples were collected from the dried plants of each models.All of these swaps and samples were transferred to microbiological laboratory directly to be tested for total aerobic bacterial count, coliform group, Staphylococcus aureus, Salmonella spp. and mold \& yeast. Results of workers hand and products contact surfaces microbial swapsshowed a significant decrease $(p \leq 0.05)$ in oven and solar dehydration respectively than natural dehydration. Also microbial test of dried products showed a significant decrease $(p \leq 0.05)$ in oven dehydrationthan solar dehydration than natural dehydration.

Keywords: Microbiological hazards, HACCP, Pre-requisite programs, medicinal and aromatic plants, Dehydration.
\end{abstract}

\section{INTRODUCTION}

Microbiological hazard analysis is a process of three components: hazard assessment, hazard management, and hazard communication. Its overall objective is to ensure public health protection. Hazard assessment is a key element in ensuring that sound science is used to establish standards, guidelines and other recommendations for food safety to enhance consumer protection and facilitate international trade. The microbiological hazard assessment process should include quantitative information to the greatest extent possible in the estimation of hazard. Pathogens can be transferred from handlers, contact surfaces or air. Surfaces, 
utensils, equipment, fixtures and fittings should be thoroughly cleaned and, where necessary, disinfected after raw food, has beenhandled or processed.(FAO and WHO, 2009).

Pre-requisite programis basic conditions and activities that are necessary to maintain a hygienic environment throughout the food chainand suitable for the production, handling and provision of safe end products for human consumption (ISO 22000, 2005).

HACCP-based programs were implemented in 1990's to enhance food safety and quality and preventing food hazards. Upon finding a food hazard in the product, the HACCP-based system of the procedures and control is assumed to have failed. Generally, little attention is given to the fact that the HACCP-based program can only minimize the probability of risk of food hazards from occurring (Cormier et al., 2007).

Formal pre-requisite programs are increasingly and successfully used to support the implementation of HACCP in food processing. However, in many areas there is a lack of understanding of the pre-requisite concept, and even a fear in some sectors that pre-requisite might dilute the strength of HACCP (Wallace and Wiliams, 2001).

Food safety is still an important issue both to citizens and to agribusiness and food industry. Increased consumer awareness and new legislative demands on food production systems have resulted in significant efforts in control measures and assurance systems in different food sectors all over the world. Moreover, new challenges in reducing incidence of food safety hazards due to typical changes in food supply chains, health and demographic situations, social situations, and environmental conditions (e.g. increased pollution), underpin the need for effective food safety management systems (FSMS). On the other hand, new and modified safety control measures and techniques are now being developed to effectively combat microbial hazards. Examples are more rapid and accurate microbial methods, more effective cleaning and disinfection methods, new processing techniques, and more effective food safety training programs. These developments offer opportunities for the improvement of current FSMS (Luninget al., 2008).

The implementation of international standards on the market represents a necessary element in the process of improving a company's competitiveness. Customer care, healthy and safe food, ecological standards represent only some of the conditions that modern business requires from producers of food products. The implementation of the HACCP (hazard analysis and critical control point) system, that is standard ISO 22000:2005 - Food safety management systems - Requirements for any organization in the food chain, represents one of many requirements directed towards companies in the function of customer health care. Its implementation is becoming compulsory for all companies whose aim is exporting products to European Union countries (EU) and the World Trade Organization (WTO) (Djordjevicet al.,2011). 
Post-harvest process such as collection of medicinal and aromatic plants material in the field, transport to the farm and drying are often suspected to increase microbial contamination of medicinal plants. When the bulk of harvested material is not ventilated, auto-heating due to respiration activity provides favorable conditions for micro-organism growth, in terms of temperature and humidity (Muller and Heindl, 2006). So that the HACCP pre-requisite program aspects should be taken in account during drying process and/or post-harvest procedure to avoid increasing of microbial hazard.

At the time of actual harvest and immediately following harvest, the herbal crop must be handled, stored, and consolidated in a manner that ensures that the collected material does not degrade in transit. Threats to product quality include, among others, cross contamination from other crops and materials, insect or other infestation, product compaction, exposure to the elements, and temperature build-up and overheating. (AHPA, 2006).

WHO, stated that raw medicinal plant materials should be inspected and sorted prior to primary processing. The inspection may includevisual inspection for crosscontamination by untargeted medicinal plants and/or plant parts, visual inspection for foreign matter, organoleptic evaluation such as: appearance, damage, size, color, odor ... etc, and possibly taste. Medicinal plant materials that are to be used in the fresh state should be harvested and delivered as quickly as possible to the processing facility in order to prevent microbial fermentation and thermal degradation. The use of preservatives should be avoided. If used, this should be documented and they should conform to national and/or regional regulatory requirements in both the source country and the end-user country.(WHO, 2003).

In case of natural drying in the open air, medicinal plant material should be spread out in thin layers on drying frames and stirred or turned frequently. In order to secure adequate air circulation, plants or part of plants should not be in direct contact with the soil. They should be placed on raised platforms or on floor made of suitable materials. If a concrete or cement surface is used, medicinal plant materials should be laid on a tarpaulin or other appropriate cloth or sheeting. Insects, rodents, birds, livestock and domestic animals should be kept away from drying sites. (Codex Alimentarius, 1995 and WHO, 2003).

In case of mechanical drying such as oven dryers all manufacturing instructions and established operating procedures to ensure the quality of the herbal material is maintained, as well as low drying temperatures between 30 and $50^{\circ} \mathrm{Care}$ recommended to protect sensitive active ingredients (Muller and Heindl, 2006). The optimal drying temperature differs for various plants and plant parts, though, in general, an air temperature of $45^{\circ} \mathrm{C}$ is appropriate for a wide range of herbal 
materials. Some plants, however, are particularly susceptible to excessive temperatures (AHPA, 2006).

Effective measures should be taken to prevent contamination of cropsby direct or indirect contact with those at earlier stages of the processing. Persons who handled raw materials and/or semi-processed products capable to contaminate product.If there is a likelihood of contamination, hands should be washed and disinfected thoroughly before handling products at different stages of processing. Raw products that may present a hazard should be processed in separate rooms, or in areas physically separated from those where end-products are being prepared. All equipment which in contact with raw or contaminated materials should be thoroughly cleaned and disinfected prior to being used for contact with end-product. Treated, ready-to-eat crops should beSalmonella free (Codex Alimentarius, 1995).

This study was aimed to improve the safety of medicinal and aromatic plants by using pest practices during post-harvest and/or proper dehydration.

\section{MATERIALS AND METHODS}

\section{Medicinal plants:}

Chamomile (Matricariachamomilla) and Calendula (Calendula officinalis) were used in this study.These twocrops were collected from K. Shanboliya farm in Elfayoumgovernorate in Egypt during winter season.

\section{Dehydration methods}

- Sun drying had been done in Shanboliya station in El-fayoum governorate in Egypt. Calendula (Calendula officinalis) flowers spread onthe floor in dehydration area directly to sun light. Chamomile (Matricariachamomilla) flowers spread in wooden baskets covered with clean papers inside. These baskets standing over each other's under grass ceiling. Drying temperature was ranged between 20 and $25{ }^{\circ} \mathrm{C}$ during February for 60 hrs.

- Solar drying had been done in Faculty of Agriculture - Cairo University. Calendula and Chamomile were dried separately on stainless steel screened plates installed on trolley inside the solar dryer in order to secure adequate air circulation which is produced by tow blowers installed on solar dryer cabinet. The average of temperature reached $35^{\circ} \mathrm{C}$ for 50 hrs for Calendula and $35^{\circ} \mathrm{C}$ for 30 hrs for Chamomile.

- Oven drying had been done in Faculty of Agriculture - Cairo University. Calendula and Chamomile were dried separately and were spread on perforated plate to produce adequate air circulation throw flowers inside the oven dryer. The oven dryer temperature was adjusted to $45^{\circ} \mathrm{C}$ according to (AHPA, 2006). The dehydration times were 27 and 18 hrs for Calendula and Chamomile respectively. 


\section{Gap analysis}

- Gap analysis of the three dehydration methods was carried out using thecommon technical aspects of good agricultural practices (GAP) and good collection practices (GCP) for medicinal plants which were reported in WHO guideline (2003) to assess the microbiological hazards in product contact surfaces, workers hands and dried crops.

\section{Cleaning and disinfectant program:}

Cleaning and disinfectant program was carried out for contact surfaces (dryers, sevier and grinder) and workers hands in both solar and oven drying. But in sundrying it was very difficult to set up cleaning and disinfectant program because the area was not hygienically illustrated.

- Contact surfaces, the program carried outusing the following steps according to HACCP-based Standard Operating Procedures (USDA and NFSMI, 2005):

1. Washing with clean water and liquid soap using brush.

2. Rinsing with potable water.

3. Disinfecting with sodium hypochlorite solution $(500 \mathrm{ppm}$ available chlorine) against vegetative bacteria, fungi and most viruses (Dvorak, 2008).

4. Rinsing with potable water again.

5. Placing wet items in a manner to allow air drying.

- Workers hands, the program was carried out using stepsof HACCP-based Standard Operating Procedures (USDA and NFSMI, 2005) as follow:

1. Washing hand by potable water.

2. Applying the disinfectant soap to hand.

3. Scrubbing hands, under fingernails, and between fingers for at least $15-20$ seconds.

4. Rinsing thoroughly under worm running water.

5. Drying hands using single-use paper towels.

\section{Microbiological evaluation:}

\section{- Microbiological medium:}

1. The aerobic bacterial counts were enumerated as recommended by A.O.A.C (1990), OXOID (1998) and Atlas (2010) using plat count agar medium.

2. The Coliform group bacteria was detected and enumerated as described and recommended by OXOID (1998) using violet red bile lactose agar medium.

3. Staphylococcus aureuswas detected and enumerated as described and recommended by OXOID (1998) using Baired-Parker agar base medium.

4. Salmonella sp. was detected and enumerated as described and recommended by OXIOD (1998) and Atlas (2010) using Salmonella Shigella agar (SS agar modified). 
5. Mold and Yeast were detected and enumerated as described and recommended by Atlas (2010) using potato dextrose agar medium.

\section{- Samples preparation:}

\section{Swap analysis:}

Swaps weresterilized with $0.9 \% \mathrm{NaCl}$ solution and each one was used to swapping $25 \mathrm{~cm} 2$ of product contact surfacesand swapping workers hands. After swabbing, the swabs were placed in sterilized test tubes containing $10 \mathrm{ml}$ of sterilized $0.9 \% \mathrm{NaCl}$ solution and were shacked well with vortex to transfer and distribute all of the microbes from swabs to solution,then deferent dilutions were prepared and $1 \mathrm{ml}$ of each dilution were spread on the surfaces of petri-dishes of the specific medium (Orion Diagnostica, 2002). Swaps were tested for aerobic bacterial count, coliform group, Staphylococcus aureus, Salmonella spp. and mold $\&$ yeast.

\section{Medicinal plants analysis:}

- A sample of $10 \mathrm{gm}$ of each plant material is suspended in $100 \mathrm{ml}$ of sterile saline solution ( $\mathrm{NaCl}$ 0.9\%) mixed well. Serial dilutions are prepared so that the number of colony-forming units (CFUs) in Petri dishes were be countable (Antoniaet al, 2010).

\section{- Statistical analysis:}

All results statistically analyzed by SAS program ver. 9.1.3 to calculate means, standard deviation, significance and Least Significant Deviation (L.S.D) at 5\%.

\section{RESULTS AND DISCUSSION}

\section{Gap analysis observations:}

\section{- Natural dehydration:}

Natural drying station almost weren't met neither the requirements of the American Herbal Products Association and American Herbal Pharmacopeia (AHPA-AHP) nor of the World Health Organization (WHO) which sighted the good practices during post-harvest of herbal and medicinal plants.

\section{- Solar dehydration:}

Solar dryer met most of the above requirements, but the temperature and relative humidity were not fully controlled and the dryer has been sighted near the grass that caused presence of some insects.

\section{- Oven dehydration:}

Oven dryer met all of the above requirements for controlled temperature, relative humidity, personal hygiene, constrictions ... etc. 


\section{Microbial count results:}

\section{- Contact surfaces:}

Table (1) and (2)show microbiological counts of contact surfaces among dehydration methods of Calendulaand Chamomile respectively. Results showa significant reduction $(p \leq .0 .05)$ of total aerobic bacteria and mold \& yeast in all contact surfaces"dehydration area, sevier and grinder" forboth oven and solar dehydration than sun dehydration. Both coliform group and Salmonella were detected in sun dryer only "dehydration area and sevier" but they were not detected in solar and oven dryers. Staphylococcus aureus was not detected in any of contact surfaces of the three dehydration methods. The highest contamination shown on contact surfaces of sun dehydration method because it wasn't implement any of the food safety requirements of FAO, WHO, CODEX and/or AHPA-AHP.

Equipment and containers coming into contact with food, should be designed and constructed to ensure that,where necessary, they can be adequately cleaned, disinfected and maintained to avoidthe contamination of food. Equipment and containers should be made of materialswith no toxic effect in intended use. Where necessary, equipment should be durableand movable or capable of being disassembled to allow for maintenance, cleaning,disinfection, monitoring and, for example, to facilitate inspection for pests (FAO and WHO, 2009).

Cutting and milling operations must be conducted withpractices that ensure that the material's quality and purity is maintained.Before conveying herbal materials intocutting or milling equipment, perform all necessary in-line cleaning andscreening steps. These may include, for example, use of a de-stoner, agravity separator, or a metal detector.Maintain all cutting and milling equipment inclean and well-functioning condition (AHPA, 2006).

Plants or parts of plants used for the preparation of spices may be dried naturally or artificially,provided adequate measures are taken to prevent contamination or alteration of the raw material during theprocess. To prevent the growth of microorganisms, especially mycotoxin producing mold, a safe moisturelevel should be achieved.If dried naturally, plants or part of plants should not be in direct contact with the soil. They should be placed on raised platforms or on a floor made of a suitable material or covered with plastic sheets. New concrete floors should be used for drying only when it is absolutely certain that the new concrete is well-cured and free of excess water. It is safer to use approved plastic sheets to cover the concrete floor as a moisture barrier prior to use for spices (CODEX, 1995).It is assumed that after cleaning and sanitizing that the surface will be clean, and total aerobic bacterial count results will be less than $5 \mathrm{CFU} / \mathrm{cm}^{2}$ (CDC, 2010), and it is compatible with the obtained results of the total aerobic bacterial counts on contact surfaces of solar and oven dryers in both tables (1) and (2) . 
Table 1. Microbiological counts of product contact surfaces among dehydration methods of Calendula officinalis (CFU/ $25 \mathrm{~cm}^{2}$ )

\begin{tabular}{|c|c|c|c|c|c|c|}
\hline \multirow[b]{2}{*}{$\begin{array}{l}\text { Methods of } \\
\text { dehydration }\end{array}$} & \multirow[b]{2}{*}{ Surfaces } & \multicolumn{5}{|c|}{ Microbial plat count } \\
\hline & & $\begin{array}{l}\text { Total } \\
\text { aerobic } \\
\text { count }\end{array}$ & $\begin{array}{c}\text { Coliform } \\
\text { group }\end{array}$ & $\begin{array}{l}\text { Staph. } \\
\text { aureus }\end{array}$ & $\begin{array}{c}\text { Salmonella } \\
s p .\end{array}$ & $\begin{array}{l}\text { Mold \& } \\
\text { Yeast }\end{array}$ \\
\hline \multirow{3}{*}{ Sun dryer } & Dehydration & $\begin{array}{l}436 \pm \\
33.92^{\mathrm{a}}\end{array}$ & $\begin{array}{l}84 \pm \\
5.29^{\mathrm{a}}\end{array}$ & N.D ${ }^{a}$ & $160 \pm 7.00^{\mathrm{a}}$ & $\begin{array}{c}152.33 \pm \\
11.68^{\mathrm{a}}\end{array}$ \\
\hline & Sevier & $\begin{array}{c}111.33 \pm \\
3.06^{\mathrm{a}}\end{array}$ & $\begin{array}{c}24.33 \pm \\
6.03^{\mathrm{a}}\end{array}$ & N.D ${ }^{a}$ & $59 \pm 3.61^{a}$ & $54 \pm 8.72^{a}$ \\
\hline & Grinder & $\begin{array}{c}114.67 \pm \\
4.16^{\mathrm{a}}\end{array}$ & N.D & N.D ${ }^{a}$ & N.D ${ }^{a}$ & $47 \pm 2.52^{\mathrm{a}}$ \\
\hline \multirow{3}{*}{ Solar dryer } & Dehydration & $30 \pm 6.00^{b}$ & $N . D^{b}$ & $N . D^{a}$ & $N . D^{b}$ & $\begin{array}{c}25.67 \pm \\
4.04^{b}\end{array}$ \\
\hline & Sevier & $\begin{array}{c}11.67 \pm \\
1.53^{\mathrm{b}}\end{array}$ & $N \cdot D^{b}$ & $N . D^{a}$ & $N \cdot D^{b}$ & $4 \pm 2.00^{b}$ \\
\hline & Grinder & $23 \pm 3.00^{b}$ & $N . D^{a}$ & $N \cdot D^{a}$ & $N \cdot D^{a}$ & $10 \pm 2.00^{b}$ \\
\hline \multirow{3}{*}{ Oven dryer } & Dehydration & $\begin{array}{c}24.67 \pm \\
6.7^{b}\end{array}$ & $N . D^{b}$ & N.D ${ }^{a}$ & $N \cdot D^{b}$ & $\begin{array}{c}22.33 \pm \\
2.52^{\mathrm{b}}\end{array}$ \\
\hline & Sevier & $\begin{array}{c}15.33 \pm \\
2.52^{\mathrm{b}}\end{array}$ & $N \cdot D^{b}$ & $N . D^{a}$ & $N . D^{b}$ & $\begin{array}{c}5.33 \pm \\
2.51^{\mathrm{b}}\end{array}$ \\
\hline & Grinder & $\begin{array}{c}18.33 \pm \\
3.05^{\mathrm{b}}\end{array}$ & $N \cdot D^{a}$ & $N . D^{a}$ & $N \cdot D^{a}$ & $\begin{array}{c}9.67 \pm \\
2.08^{\mathrm{b}}\end{array}$ \\
\hline \multirow{3}{*}{ L.S.D at $5 \%$} & Dehydration & 39.44 & 6.10 & 0.00 & 8.07 & 14.55 \\
\hline & Sevier & 4.89 & 6.95 & 0.00 & 4.16 & 10.72 \\
\hline & Grinder & 6.89 & 0.00 & 0.00 & 0.00 & 4.42 \\
\hline
\end{tabular}


Table 2. Microbiological counts of product contact surfaces among dehydration methods ofChamomile (Matricariachamomilla) $\left(\mathrm{CFU} / 25 \mathrm{~cm}^{2}\right.$ )

\begin{tabular}{|c|c|c|c|c|c|c|}
\hline \multirow[b]{2}{*}{$\begin{array}{l}\text { Methods of } \\
\text { dehydration }\end{array}$} & \multirow[b]{2}{*}{ Surfaces } & \multicolumn{5}{|c|}{ Microbial plat count } \\
\hline & & $\begin{array}{c}\text { Total } \\
\text { aerobic } \\
\text { count }\end{array}$ & $\begin{array}{c}\text { Coliform } \\
\text { group }\end{array}$ & $\begin{array}{l}\text { Staph. } \\
\text { aureus }\end{array}$ & $\begin{array}{c}\text { Salmonella } \\
\text { sp. }\end{array}$ & $\begin{array}{l}\text { Mold \& } \\
\text { Yeast }\end{array}$ \\
\hline \multirow{3}{*}{ Sun dryer } & Dehydration & $\begin{array}{c}247.33 \pm \\
12.22^{\mathrm{a}}\end{array}$ & $\begin{array}{c}25.33 \pm \\
4.04^{\mathrm{a}}\end{array}$ & $N \cdot D^{a}$ & $\begin{array}{c}100.67 \pm \\
11.02^{\mathrm{a}}\end{array}$ & $136 \pm 6.00^{\mathrm{a}}$ \\
\hline & Sevier & $\begin{array}{l}111 \pm \\
10.15^{\mathrm{a}}\end{array}$ & $\begin{array}{l}21 \pm \\
3.61^{\mathrm{a}}\end{array}$ & $N . D^{a}$ & $68.33 \pm 3.06^{a}$ & $\begin{array}{c}43.33 \pm \\
7.64^{\mathrm{a}}\end{array}$ \\
\hline & Grinder & $\begin{array}{l}106 \pm \\
8.54^{\mathrm{a}}\end{array}$ & N.D ${ }^{a}$ & $N \cdot D^{a}$ & $N . D^{a}$ & $\begin{array}{c}47.67 \pm \\
2.52^{\mathrm{a}}\end{array}$ \\
\hline \multirow{3}{*}{ Solar dryer } & Dehydration & $\begin{array}{c}46.67 \pm \\
6.11^{\mathrm{b}}\end{array}$ & $N \cdot D^{b}$ & $N \cdot D^{a}$ & $N \cdot D^{b}$ & $\begin{array}{c}30.33^{ \pm} \\
3.51^{\mathrm{b}}\end{array}$ \\
\hline & Sevier & $\begin{array}{c}12.67 \pm \\
2.52^{\mathrm{b}}\end{array}$ & $N \cdot D^{b}$ & $N \cdot D^{a}$ & $N \cdot D^{b}$ & $\begin{array}{c}3.67 \pm \\
1.53^{\mathrm{b}}\end{array}$ \\
\hline & Grinder & $\begin{array}{c}20.67 \pm \\
3.06^{b}\end{array}$ & N.D ${ }^{a}$ & $N \cdot D^{a}$ & $N \cdot D^{a}$ & $\begin{array}{c}9.33 \pm \\
1.20^{\mathrm{b}}\end{array}$ \\
\hline \multirow{3}{*}{ Oven dryer } & Dehydration & $\begin{array}{c}34.33 \pm \\
3.06^{\mathrm{b}}\end{array}$ & $N \cdot D^{b}$ & $N \cdot D^{a}$ & $N . D^{b}$ & $\begin{array}{c}27.67 \pm \\
2.51^{b}\end{array}$ \\
\hline & Sevier & $\begin{array}{c}17.67 \pm \\
2.52^{\mathrm{b}} \\
\end{array}$ & $N . D^{b}$ & $N \cdot D^{a}$ & $N \cdot D^{b}$ & $\begin{array}{c}4.67 \pm \\
1.76^{\mathrm{b}}\end{array}$ \\
\hline & Grinder & $\begin{array}{l}21 \pm \\
7.21^{\mathrm{b}}\end{array}$ & N.D ${ }^{a}$ & $N \cdot D^{a}$ & $N \cdot D^{a}$ & $9.67 \pm 1.5^{b}$ \\
\hline \multirow{3}{*}{ L.S.D at $5 \%$} & Dehydration & 16.15 & 4.66 & 0.00 & 12.71 & 8.53 \\
\hline & Sevier & 12.41 & 4.16 & 0.00 & 3.52 & 9.65 \\
\hline & Grinder & 13.37 & 0.00 & 0.00 & 0.00 & 4.16 \\
\hline
\end{tabular}




\section{- Worker's hands:}

Table (3) and (4) show Microbiological analysis of swaps taken from worker's hands on dehydration methods of Calendulaand chamomile respectively. A significant decrease $(p \leq 0.05)$ on total aerobic count and mold \& yeast for workers hands of oven and solar dehydration respectively than that ofsun dehydration. Pathogenic bacteria (Coliform group, Staphylococcus aureus and Mold \& Yeast) were not detected on worker's hands of oven and solar dehydration methods, but they were detected on workers hands of sun dehydration methods.

Hands should always be washed before starting work,immediately after using the bathroom, after handling the contaminated material and wherever else necessary (WHO, 2003). Afterhandling any material which might be capable of transmitting microbes, hands should be washed and disinfectedimmediately. Notices requiring hand-washing should be displayed. There should be adequate supervision toensure compliance with this requirement as reported by CODEX (1995) and FAO and $\mathrm{WHO}(2009)$.

Preventing contamination should be reached by provide a person who handle herbalplant materials with adequatetraining in proper personal hygiene, with specific attention to preventingmicrobial contamination of handled crops (AHPA, 2006).

The hands may becomepersistently colonized by pathogenic flora suchas Staphylococcusaureus,Gram-negative bacilli, or yeast. The obtained results in tables (3) and (4) revealed that total bacterial count is less than of those reported by FAO (2009)which were ranged from $3.9 \times 104$ to $4.6 \times 106 \mathrm{CFU} / \mathrm{cm} 2$.

\section{- Dried medicinal plants:}

Table (5) and (6) show the microbial load of Calendulaand chamomilerespectively. Table (5) shows a significant decrease $(p \leq 0.05)$ in total aerobic and mold \& yeast counts of oven dehydrated calendula than solar andsun dehydrated one. Pathogenic bacteria (coliform group, Staphylococcusaureus and Salmonella sp.) were detected in sun dehydrated calendula only, but were not detected in both solar and oven dehydrated one. Table (6) shows almost the same significant decrease $(p \leq 0.05)$ in total aerobic and mold \& yeast counts of oven dehydrated chamomile than solar andsun dehydrated one. Only coliform group and Salmonella were detected in sun dehydrated chamomile.Meanwhile,staphylococcusaureus was not detected yet in sun, solar or oven dehydrated chamomile. 
Table 3. Microbiological analysis of swaps taken from worker's hands on dehydration methods of Calendula officinalis (CFU/hand).

\begin{tabular}{|c|c|c|c|c|c|}
\hline \multirow[b]{2}{*}{$\begin{array}{l}\text { Methods of } \\
\text { dehydration }\end{array}$} & \multicolumn{5}{|c|}{ Microbial plat count $\times 10^{2}$} \\
\hline & $\begin{array}{c}\text { Total } \\
\text { aerobic } \\
\text { count }\end{array}$ & $\begin{array}{l}\text { Coliform } \\
\text { group }\end{array}$ & $\begin{array}{l}\text { Staph. } \\
\text { aureus }\end{array}$ & $\begin{array}{c}\text { Salmonella } \\
\text { sp. }\end{array}$ & Mold \& Yeast \\
\hline Sun dryer & $\begin{array}{l}2390 \pm \\
149.33^{\mathrm{a}}\end{array}$ & $\begin{array}{c}883.33 \pm \\
152.75^{\mathrm{a}}\end{array}$ & $\begin{array}{c}127.33 \pm \\
7.51^{\mathrm{a}}\end{array}$ & $\begin{array}{c}686.67 \pm \\
80.83^{\mathrm{a}}\end{array}$ & $\begin{array}{c}503.33 \pm \\
55.08^{\mathrm{a}}\end{array}$ \\
\hline Solar dryer & $30 \pm 4.58^{b}$ & $N \cdot D^{b}$ & $N \cdot D^{b}$ & $N \cdot D^{b}$ & $8 \pm 2.6^{b}$ \\
\hline Oven dryer & $\begin{array}{c}16.33 \pm \\
1.53^{\mathrm{b}}\end{array}$ & $N . D^{b}$ & $N . D^{b}$ & N.D ${ }^{b}$ & $3 \pm 1.0^{b}$ \\
\hline L.S.D at $5 \%$ & 172.34 & 176.20 & 8.68 & 93.24 & 63.61 \\
\hline
\end{tabular}

Table 4. Microbiological analysis of swaps taken from worker's hands on dehydration methods of Chamomile (Matricariachamomilla) (CFU/hand).

\begin{tabular}{|c|c|c|c|c|c|}
\hline \multirow[b]{2}{*}{$\begin{array}{l}\text { Methods of } \\
\text { dehydration }\end{array}$} & \multicolumn{5}{|c|}{ Microbial plat count $\times 10^{2}$} \\
\hline & $\begin{array}{c}\text { Total } \\
\text { aerobic } \\
\text { count }\end{array}$ & $\begin{array}{l}\text { Coliform } \\
\text { group }\end{array}$ & $\begin{array}{l}\text { Staph. } \\
\text { aureus }\end{array}$ & $\begin{array}{c}\text { Salmonella } \\
\text { sp. }\end{array}$ & Mold \& Yeast \\
\hline Sun dryer & $\begin{array}{c}1913.33 \pm \\
212.21^{\mathrm{a}}\end{array}$ & $\begin{array}{l}1100 \pm \\
78.10^{\mathrm{a}}\end{array}$ & $\begin{array}{c}28.33 \pm \\
3.51^{\mathrm{a}}\end{array}$ & $\begin{array}{c}236.67 \pm \\
13.01^{\mathrm{a}}\end{array}$ & $381 \pm 29.21^{a}$ \\
\hline Solar dryer & $17 \pm 67^{b}$ & $N . D^{b}$ & $N \cdot D^{b}$ & $N . D^{b}$ & $\begin{array}{c}10.33 \pm \\
1.53^{\mathrm{b}}\end{array}$ \\
\hline Oven dryer & $\begin{array}{c}16.33 \pm \\
1.53^{\mathrm{b}}\end{array}$ & $N . D^{b}$ & $N \cdot D^{b}$ & $N \cdot D^{b}$ & $2.67 \pm 1.53^{b}$ \\
\hline L.S.D at $5 \%$ & 244.81 & 90.09 & 4.05 & 15.01 & 33.78 \\
\hline
\end{tabular}

Microbial limit testing is seen as an attribute of Good Manufacturing Practice, as well as of quality assurance. It is advisable to test the herbal medicinal product unless its components are tested before manufacture and the manufacturing process is known, through validation studies, not to carry a significant risk of microbial contamination. Where appropriate, acceptance criteria should be set for the total count of aerobic microorganisms, the total count of yeasts and molds, and the absence of specific objectionable bacteria (e.g. Staphylococcus aureus, Escherichia coli, Salmonella, Pseudomonas) (EMEA, 2006). 
Total viable aerobic count should be not more than 107 bacteria, 103 fungi and 102 E. coli per gram in herbal medicinal preparation which boiling water is added before use, but in herbal plants which is boiling water is not added before use, total viable aerobic count should be not more than 105 bacteria, 104 fungi and absence of E. coli per gram (Antonia et al, 2010).

Chamnawanget al, 2003 evaluated the microbial quality of herbal products and reported that $5.0 \times 105 \mathrm{CFU} / \mathrm{gm}$ of total aerobic count, $5.0 \times 103 \mathrm{CFU} / \mathrm{gm}$ of mold and yeast, $50 \mathrm{CFU} / \mathrm{gm}$ of E. coliand presence of Staph. aureus and Salmonella spp. Table 5. Microbiological analysis of dried Calendula(Calendula officinalis)(CFU/gm).

\begin{tabular}{|c|c|c|c|c|c|}
\hline \multirow[b]{2}{*}{$\begin{array}{l}\text { Methods of } \\
\text { dehydration }\end{array}$} & \multicolumn{5}{|c|}{ Microbial plat count $\times 10^{2}$} \\
\hline & $\begin{array}{c}\text { Total } \\
\text { aerobic } \\
\text { count }\end{array}$ & $\begin{array}{c}\text { Coliform } \\
\text { group }\end{array}$ & $\begin{array}{l}\text { Staph. } \\
\text { aureus }\end{array}$ & $\begin{array}{l}\text { Salmonella } \\
\text { spp. }\end{array}$ & Mold \& Yeast \\
\hline Sun dryer & $\begin{array}{c}606.67 \pm \\
51.32^{\mathrm{a}}\end{array}$ & $\begin{array}{c}59.33 \pm \\
5.13^{\mathrm{a}}\end{array}$ & $\begin{array}{c}10.33 \pm \\
2.52^{\mathrm{a}}\end{array}$ & $\begin{array}{c}211.33 \pm \\
10.26^{\mathrm{a}}\end{array}$ & $226 \pm 26.23^{\mathrm{a}}$ \\
\hline Solar dryer & $\begin{array}{c}154.67 \pm \\
5.03^{b}\end{array}$ & $N . D^{b}$ & $N \cdot D^{b}$ & $N . D^{b}$ & $75 \pm 3.00^{b}$ \\
\hline Oven dryer & $51 \pm 3.61^{c}$ & $N \cdot D^{b}$ & N.D $D^{b}$ & $N . D^{b}$ & $\begin{array}{c}35.67 \pm \\
4.04^{c}\end{array}$ \\
\hline L.S.D at $5 \%$ & 59.62 & 5.92 & 2.90 & 11.84 & 30.18 \\
\hline
\end{tabular}

Table 6. Microbiological analysis of dried Chamomile(Matricariachamomilla)(CFU/gm)

\begin{tabular}{|c|c|c|c|c|c|}
\hline \multirow[b]{2}{*}{$\begin{array}{l}\text { Methods of } \\
\text { dehydration }\end{array}$} & \multicolumn{5}{|c|}{ Microbial plat count $\times 10^{2}$} \\
\hline & $\begin{array}{c}\text { Total } \\
\text { aerobic } \\
\text { count }\end{array}$ & $\begin{array}{c}\text { Coliform } \\
\text { group }\end{array}$ & $\begin{array}{l}\text { Staph. } \\
\text { aureus }\end{array}$ & $\begin{array}{c}\text { Salmonella } \\
\text { spp. }\end{array}$ & Mold \& Yeast \\
\hline Sun dryer & $\begin{array}{c}150.67 \pm \\
4.04^{\mathrm{a}}\end{array}$ & $\begin{array}{c}32.33 \pm \\
2.52^{\mathrm{a}}\end{array}$ & N.D ${ }^{a}$ & $9.67 \pm 2.52^{\mathrm{a}}$ & $\begin{array}{c}48.33 \pm \\
4.73^{\mathrm{a}}\end{array}$ \\
\hline Solar dryer & $\begin{array}{c}94.33 \pm \\
6.03^{b}\end{array}$ & $N . D^{b}$ & $N . D^{a}$ & $N \cdot D^{b}$ & $30 \pm 2.00^{\mathrm{b}}$ \\
\hline Oven dryer & $31 \pm 3.61^{c}$ & $N . D^{b}$ & $N \cdot D^{a}$ & $N . D^{b}$ & $\begin{array}{c}17.67 \pm \\
2.52^{c}\end{array}$ \\
\hline L.S.D at $5 \%$ & 9.35 & 2.90 & 0.00 & 2.90 & 6.59 \\
\hline
\end{tabular}




\section{CONCLUSION}

Results show that the bestdehydration methods of medicinal and aromatic plants are oven drying and solar drying respectively.

Cleaning and disinfectance programs of product contact surfaces and worker's hand should be carried out because it has direct effects on products safety.

Prerequisites programs of HACCP system should be implemented in post-harvest of medicinal and aromatic plants to reduce the microbiological load and reduce the energy coasts used for sterilizing the end products of medicinal and aromatic crops using irradiation or other techniques could be used in these aspects.

\section{ACKNOWLEDGEMENTS}

Authors would to thank Mr. Kamal Shanbolyia the owner of Shanbolyia dehydration station for his supplementation of collecting fresh plants and swaps from worker's hands, product contact surfaces and dried medicinal plants of the station (natural dehydration). this study was supported by Faculty of Agriculture - Cairo University and Food Technology Research Institute (FTRI).

\section{REFERENCES}

1. A.O.A.C. 1990. Official Methods of Analysis of the Association of Official Analytical Chemists. $15^{\text {th }}$ ed., Arlington, Verginia, U.S.A.

2. American Herbal Products Association (AHPA) and American Herbal Pharmacopoeia (AHP) 2006. Good Agricultural and Collection Practice for Herbal Raw Materials. pp 32

3. Antonia, P., T. Cristina, G. Elvira, C. Aprotosoaie, S. Ursula, and H. Monica. 2010. The Microbial Level Contamination in Dried Plant Material Evaluated by The Standard Plate Count. NaturaMontenegrina, Vol. 9 (3): 883-887

4. Atlas, R. M. 2010. Handbook of Microbiological Media. $4^{\text {th }}$ ed. CRC press, Taylor \& Francis Group, Boca Raton, London, New York. ISBN 13: 978-1-4398-0408-7, pp 2036

5. Center for Disease Control (CDC) 2010. Environmental Hygiene Monitoring - A Guide for Environmental Health Officers. Ver. 3, pp 16

6. Chomnawang, M., P. Paojinda, N. Narknopmanee and L. Rungreangyingyod 2003. Evaluation of Microbiological Quality of Herbal Products in Thailand.Thai Journal of Phytopharmacy, Vol.10(2): 37-48

7. Codex Alimentarius Commission. 1995. Codeof Hygienic Practicefor Spicesand Dried Aromatic Plants. CAC/RCP 42.pp 17 
8. Cormier, R. J., M. Mallet, S. Chiasson, H. Magnusson and G. Valdimarsson. 2007. Effectiveness and Performance of HACCP-based Programs.Food Control, Vol. 18: 665-671

9. Djordjevic, D., D. Cockalo and S. Bogetic. 2011. An Analysis of the HACCP System Implementation- The Factor of Improving Competitiveness in Serbian Companies.African Journal of Agricultural Research Vol. 6(3): 515-520

10. Dvorak G. 2008. Disinfection 101.Center for Food Security and Public Health. www.cfsph.iastate.edu. pp 22.

11. European Medicines AgencyInspections (EMEA) 2006. Guidlineon Specifications:Test Proceduresand Acceptance Criteriafor Herbal Substances,Herbal Preparation and Herbal Medicinal Products / Traditional Herbal Medicinal Products. http://www.emea.eu.int. pp 21

12. FAO and WHO 2009. Food hygiene. Codex AlimentariusCommission, $4^{\text {th }}$ ed. ISBN 978-92-5-105913-5.pp 128

13. International Standard ISO 22000 2005. Food Safety Management Systems Requirements for any Organization in the Food Chain. $1^{\text {st }}$ ed., Switzerland.pp 32

14. Luning, P. A., L. Bango, J., Kussaga, J. Rovira, and W. J. Marcelis. 2008. Comprehensive Analysis and Differentiated Assessment of Food Safety Control Systems: ADiagnostic Instrument. Trends in Food Science \& Technology 19: 522534

15. Muller, J. and A. Heindl. 2006. Drying of Medicinal Plants. In: "Medicinal and Aromatic Plants" (Eds. Bogers, R. J., Craker, L. E. and Lange, D.), Netherlands, Chapter 17, p. 237-252

16. Orion Diagnostica. 2002. A Guide to MonitoringSurface Hygiene. KirjapainoSnellman, Finland, $1^{\text {st }}$ ed, pp. 36

17. OXOID 1998. The OXOID Manual. $8^{\text {th }}$ ed., Published by OXOID Limited, Wade Road, Basingstoke,Hampshire, RG24 8PW, England, 2, pp. 231

18. USDA and NFSMI 2005. HACCP-BasedStandard OperatingProcedures. (Eds. National Food Service Management Institute, The University of Mississippi), pp. 115

19. Wallace, C. and T. William. 2001. Pre-requisite: A help or a hindrance to HACCP? Food Control, 12: 235-240

20. WHO. 2003.WHOGuidelines on Good Agricultural and Collection Practices(GACP)for Medicinal Plants. WHO Press, Geneva, pp. 71

21. WHO. 2009. WHO Guidelines on Hand Hygiene in Health Care.WHO Library Cataloguing-in-Publication Data, ISBN 978924159790 6, pp. 262 


\title{
مقارنة تقييم المخاطر الميكروبيولوجية بين ثلاث طرق تجفيف مختلفة لنباتي الكاموميل وإلكالينديولا
}

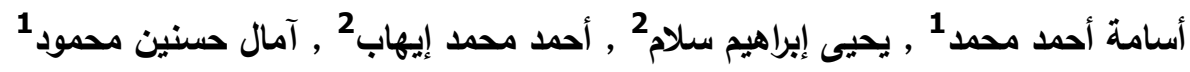 \\ 1. معهُ بحوث نكنولوجيا الأغذبة - مركز البحوث الزراعية

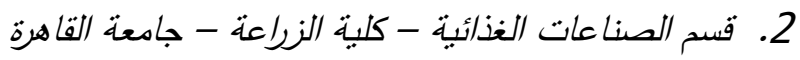

تم تقييم المخاطر الميكروبيولوجية لتحديد تأثير نطبيق البرامج التمهيدية لنظام تحليل المخاطر ونقاط التحكم الحرجة (هاسب) وطرق التجفيف المختلفة على المخاطر الميكروبيولوجية في النباتات الطبية والعطرية. نم عمل دراسة تحليل الفجوة على ثلاثة طرق تجفيف لتحديد إمكانية تطبيق البرامج التمهيدية لنظام هاسب. وكانت أحد هذة الطرق هي التجفيف الطبيعي والذي كانت به بعض العوائق الإنشائية التي تعوق تطبيق البرامج التمهيدية. أما الطرق الأخرى فكانت التجفيف الثمسي والتجفيف بالأفران والتي كانت قابلة لتطبيق تلك البرامج التمهيدية. وقد قامت الدراسة بمقارنة المخاطر الميكروبية بين

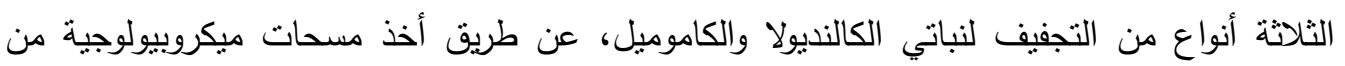
أيدي العاملين والأسطح الملامسة للمنتج من الثلاثة طرق تجفيف. كما تم أخد عينات من النباتات المجفقة من كل طريقة لتحليلها ميكربيولوجياً، حيث تم تقدير العد الكلي للبكتيريا ومجموعة بكتيريا القولون والبكتيريا العنقودية والسالمونيلا والفطريات والخمائر في جميع المسحات والعينات المأخوذة.

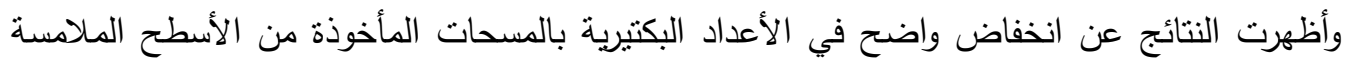
والعاملين في حالة التجفيف بالأفران والتجفيف الثمسي عن التجفيف الطبيعي. كما أظهرت النتائج إنخفاض واضح في الحمل الميكروبي للنباتات المجففة بالفرن عن المجفة شمسياً عن المجفة طبيعياً. 